Creative Commons User License: CC BY-NC-ND

Abstracted by: EBSCOhost, Electronic Journals Service (EJS),

Google Scholar, Journal Seek, Scientific Commons,

Food and Agricultural Organization (FAO), CABI and Scopus
Journal of Agricultural Extension

Vol. 25 (2) April, 2021

ISSN(e): 24086851; ISSN(Print); 1119944X

http://journal.aesonnigeria.org

http://www.ajol.info/index.php/jae

Email: editorinchief@aesonnigeria.org

\title{
Smallholder Sugarcane Farmers' Participation and Profitability of Factory Contracted Services in Malava Sub-County, Kenya
}

https://dx.doi.org/10.4314/jae.v25i2.5

\author{
Ambetsa, Francis Lekololi \\ Department of Agricultural Economics and Extension, \\ University of Embu, Kenya. \\ Email: lekololi.francis@embuni.ac.ke \\ Phone: +254700086081 \\ Ndirangu, Samuel Njiri \\ Department of Agricultural Economics and Extension, \\ University of Embu, Kenya. \\ Email: ndirangu.samuel@embuni.ac.ke \\ Phone: +254723987104

\section{Mwangi, Samuel Chege} \\ Department of Agricultural Economics and Extension, \\ University of Embu, Kenya. \\ Email: mwangi.samuel@embuni.ac.ke
}

\section{Abstract}

This study evaluated the effect of participation in factory contracted services on the profitability of smallholder sugarcane farmers in Malava Sub-county in Western Kenya. Primary data were collected using structured questionnaire from a sample of 384 farmers using systematic random sampling and proportionate sampling. Analysis of variance was applied to determine if there was a significant difference between profitability of contracted and non-contracted farmers. The effect of contracted services on profitability among contract farmers was analyzed by multiple linear regression. The results showed that contracted extension, labour and credit services had significant effect on farmers' gross margins. The Kenyan government should formulate policies that enhance provision of contracted extension, labour and credit services. The need for a review of the existing contract engagement terms among sugarcane farmers is also evident in this study.

Keywords: smallholder farms, sugarcane, contracted services, gross margins

\section{Introduction}

In Kenya, sugarcane production is one of the major employers and contributors to the national economy alongside tea, coffee, horticulture and maize (Republic of Kenya, 2020). The sugarcane subsector contributes about 15 percent to the nation's Agricultural Gross Domestic Product (GDP) and an approximately 25 percent of the Kenyan population rely on the 
Creative Commons User License: CC BY-NC-ND

Abstracted by: EBSCOhost, Electronic Journals Service (EJS), Google Scholar, Journal Seek, Scientific Commons,

Food and Agricultural Organization (FAO), CABI and Scopus
Journal of Agricultural Extension

Vol. 25 (2) April, 2021

ISSN(e): 24086851; ISSN(Print); 1119944X

http://journal.aesonnigeria.org

http://www.ajol.info/index.php/iae

Email: editorinchief@aesonnigeria.org

subsector for their living (Wekesa, Onguso, Nyende \& Wamocho, 2015). The production of sugarcane is mainly in Western Kenya where it is dominated by smallholder farmers. The sugarcane subsector has however continued to perform dismally over the years despite its importance to the economy. Mulianga, Ogeda and Mwanga (2015), in their study to assess the effect of climate change on sugarcane productivity in Kenya indicated that sugarcane production has been on constant decline over time. Kenya Sugar Board (2016) found out that on average, cane production stands at 60 tonnes per hectare. This concurs with a study by Wekesa et al. (2015) who found a reduction of 33 percent from the 1996 level of 90 tonnes per hectare. Kenyan sugar sector has been very uncompetitive and largely survives on high tariff and non-tariff trade protection (Republic of Kenya, 2020). The domestic demand for sugar is higher than production capacity in the country (Wekesa et al., 2015). During the year 2018, local sugar production was about 490,704 tonnes which is only $57 \%$ of the domestic demand that currently stands at 850,000 tonnes (Republic of Kenya, 2020). The deficit is met through importation from the Common Market for East and Southern Africa (COMESA) countries.

Sugarcane production in Kenya is largely through contract farming. The introduction of contract farming in Kenya was expected to offer great chances for commercializing smallholder agricultural production thereby improving their productivity, and hence increasing their income (Musungu \& Sorre, 2017). The objective of introducing contract farming among smallholder farmers was to solve certain problems and limitations that smallscale farmers face in farming activities (Mishra, Kumar, Joshi \& D'Souza, 2018). Studies have indicated that there are different reasons for smallholder farmers and factories to engage in contracted services. A study by Azumah, Donkoh and Ehiakpor (2016) showed that producers and processors are likely to select contract farming instead of vertical integration or spot market exchange to minimize risks and transaction costs. The main potential reasons why farmers enter into contract farming are market security, access to technical assistance, access to capital, skill transfer and income stability (Sopheak, 2015). Knowledge and skills gained by smallholder farmers through improved technology in production provided by contracting firms enable them to increase production yields (Kumar, Roy, Tripathi, Joshi \& Adhikari, 2018). The knowledge can also be applied by farmers to other crops other than the contracted crop. In addition, input supply by the contracting factories enables smallholders to overcome their financial constraints in production (Bidzakin, Fialor, Awunyo-Vitor \& Yahaya, 2020). For the two parties engaged in the contract however, there is need for complete contract and availability of enforcement controls to prevent contract breach (Chamberlain \& Anseeuw, 2017). Contracting factories encounter high transaction costs in managing and monitoring a large number of spatially dispersed smallholder farmers (Abdulai \& Al-hassan, 
Creative Commons User License: CC BY-NC-ND

Abstracted by: EBSCOhost, Electronic Journals Service (EJS),

Google Scholar, Journal Seek, Scientific Commons,

Food and Agricultural Organization (FAO), CABI and Scopus
Journal of Agricultural Extension

Vol. 25 (2) April, 2021

ISSN(e): 24086851; ISSN(Print); 1119944X

http://journal.aesonnigeria.org

http://www.ajol.info/index.php/jae

Email: editorinchief@aesonnigeria.org

2016). These costs are subsequently transferred to the smallholder farmers through increased interest rates and high priced services, among others.

Despite contracted services offered by contracting firms aimed at improving sugarcane productivity, experiences from various smallholder sugarcane farmers in Kenya indicated deteriorating effects on production and their livelihoods (Musungu \& Sorre, 2017). Practical observations have shown that some of the sugarcane farmers have discontinued production under contract terms due to high costs incurred (Republic of Kenya, 2020). Though some farmers consider contract engagement to be expensive, over half of the farmers in Western Kenya are still engaged in contract farming (Mulianga et al., 2015). There is lack of unanimity in the literature on the impact of contract farming on the welfare and profitability of smallholder sugarcane farmers. Azumah et al. (2016), argued that contract farming improves access to markets hence more income. On the other hand, some authors view contract farming as an avenue by which contracting firms or factories exploit smallholder farmers (Abdulai \& Al-hassan, 2016; Mwambi, Oduol, Mshenga \& Saidi, 2016; Ragasa, Lambrecht \& Kufoalor, 2017). It is hence seen beneficial to some but exploitive to others. This study examined the effect of participation in factory contracted services on the profitability of smallholder sugarcane farmers in Malava Sub-county in Western Kenya.

\section{Methodology}

The study was conducted in Malava Sub-county of Kakamega County in Kenya. Malava Sub-county lies between latitudes $0^{\circ} 26^{\prime} 54^{\prime \prime} \mathrm{N}$ and $0^{\circ} 29^{\prime} 44^{\prime \prime} \mathrm{N}$; and longitudes $34^{\circ} 50^{\prime} 15^{\prime \prime} \mathrm{E}$ and $34^{\circ} 52^{\prime} 25^{\prime}$ 'E. This Sub-county is one of the areas in western part of Kenya which is dominated by sugarcane growing activities. The location of this area is mainly in Lower Midland (LM) Zone 2-3 and Upper Midland (UM) Zone 4 Agro-ecological zones (Kenya National Bureau of Statistics, 2019) where growing of sugarcane is the main economic activity. There are seven administrative units (wards) in Malava Sub-county which include West Kabras, Chemuche, East Kabras, Butali/Chegulo, Manda-Shivanga, Shirugu-Mugai and South Kabras.

The sample size for the study was 384 respondents determined through Fischers formula as applied by Mwangi, Ndirangu and Isaboke (2020).

$$
\mathrm{n}=\frac{z^{2}(p)(q)}{\varepsilon^{2}}
$$

Where: $n$ is the sample size, $z$ is the standardized normal deviation set at 1.96 to $95 \%$ confidence level, $p$ is the sample proportion (0.5), while $\varepsilon$ is the margin of error which is 0.05 since the estimate of the study was within $5 \%$ of the true value. 
Using Equation 1 and assuming 50 percent probability that the respondent has the characteristic being measured, the sample size was determined as shown below;

$$
\mathrm{n}=\frac{1.96^{2}(0.5)(1-0.5)}{0.05^{2}}=384
$$

All the seven administrative units (Wards) in Malava Sub-county were purposively selected due to their agrarian potential for sugarcane production. The sample size of respondents from each administrative unit was selected through a proportionate sampling technique (Mwololo, Nzuma, Ritho \& Aseta, 2019).

$$
n_{i}=\frac{N_{i} \times \mathrm{n}}{\mathrm{N}}
$$

Where, $n_{i}$ is the number of sugarcane farmers interviewed in the selected wards, $N_{i}$ is the total number of the sugarcane farmers in the selected Ward, $\mathrm{n}$ is the sample size for the study while $\mathrm{N}$ is the total number of sugarcane farmers in the area of study.

Table 1 shows the sample size of respondents from each administrative unit determined using equation 3.

Table 1: Study population and sample size of respondents from each administrative unit.

\begin{tabular}{lll}
\hline Administrative units & Sampling frame & Sample size \\
\hline West kabaras & 28041 & 45 \\
Chemuche & 30745 & 50 \\
East kabaras & 27659 & 45 \\
Butali/chegulo & 36876 & 59 \\
Manda-shivanga & 39194 & 63 \\
Shirugu-mugai & 32055 & 52 \\
South kabaras & 43523 & 70 \\
Total & 238093 & 384 \\
\hline
\end{tabular}

Lastly, a systematic random sampling technique was applied to select farmers to be interviewed in each Ward. Multicollinearity problem among the explanatory variables was tested using variance inflation factors (VIF). 


\section{Model specification.}

Gross margin refers to the profitability of a production process in the short run when some inputs are fixed. Gross margin is the difference between the value of gross output and variable cost of an enterprise (Mdoda \& Obi, 2019). The formula below was applied in calculating the gross margin:

$$
G M=G R-V C
$$

(4)

Where: GM is the gross margin per acre, GR is gross revenue per acre while $\mathrm{VC}$ is the variable costs associated in production per acre.

The average gross margin was determined for both the contracted and noncontracted sugarcane farmers. The analysis of variance (ANOVA) which is a statistical technique for testing differences among means by analyzing variance was applied in this study to understand whether variations in gross margins were dependent on contract engagement among smallholder sugarcane farmers in Malava Sub-county

The determination of effect of factory contracted services on profitability of smallholder sugarcane production was done using multiple linear regression analysis where gross margin per acre was used as proxy for profitability. The model used is as shown in Equation 5:

$Y_{\bar{i}}=\delta_{0}+\delta_{1} C_{1}+\delta_{2} C_{2}+\delta_{3} C_{3}+\delta_{4} C_{4}+\delta_{5} C_{5}+\delta_{6} C_{6}+\delta_{7} C_{7}+e_{i}$

Where $Y_{i}$ is the profitability measured by gross margin per acre, $\delta_{0}$ is the intercept of the function while $\delta_{1}, \delta_{2}, \delta_{3}, \delta_{4}, \delta_{5}, \delta_{6}, \delta_{7}$ are vectors of unknown scalar parameters associated with provision of contracted services to be estimated.

$C_{1}, C_{2}, C_{3}, C_{4}, C_{5}, C_{6}$ and $C_{7}$ are dummy variables for provisions of labour, sugarcane cutting, fertilizer, agrochemicals, extension services, transport services and credit services respectively while $e_{i}$ is the disturbance term.

\section{Results and Discussion}

\section{Participation in Contract Farming}

The results in Table 2 indicate the distribution of farmers participating in contract farming. The results indicate that the majority of the respondents $(65.9 \%)$ were non-contracted, with only $34.1 \%$ engaging in contract farming. This may be associated to a situation where critical aspects of the contract, such as the pricing and grading mechanisms, benefits of engagement among others are not fully shared with the farmers. Other studies revealed that contracts are less likely to succeed under conditions of mistrust resulting from information asymmetry (Dube \& Mugwagwa, 2017; Kumar et al., 2018; Le-Ngoc, 2018; Musa, Van \& Retief, 2018). Information asymmetry is a situation where one party has more or better information 
Creative Commons User License: CC BY-NC-ND

Abstracted by: EBSCOhost, Electronic Journals Service (EJS),

Google Scholar, Journal Seek, Scientific Commons,

Food and Agricultural Organization (FAO), CABI and Scopus
Journal of Agricultural Extension

Vol. 25 (2) April, 2021

ISSN(e): 24086851; ISSN(Print); 1119944X

http://journal.aesonnigeria.org

http://www.ajol.info/index.php/jae

Email: editorinchief@aesonnigeria.org

than the other party which creates an imbalance of power in transactions (Musa, Van \& Retief, 2018).

Table 2: Contract engagement of sugarcane farmers

\begin{tabular}{ll}
\hline Factory & Percentage. $(\mathbf{n}=\mathbf{3 8 4})$ \\
\hline Contracted farmers & 34.1 \\
Non-contracted farmers & 65.9 \\
\hline
\end{tabular}

\section{Contracted Services Offered}

Table 3 shows a summary of contracted services offered to 131 of farmers who engage in contract farming. The results show that the majority of farmers who engage in contract farming are provided with labour, seed-cane and fertilizer which is represented by $69.5,80.2$ and 72.5 percent of respondents respectively. Other services provided to the majority of farmers are extension services, transport services and cash credit with 64.9, 72.5 and 70.2 percent of respondents respectively. This implies that the majority of farmers who engage in contract farming are provided with key inputs and services to improve their productivity. The results also show that only $2.3 \%$ of respondents receive agrochemicals implying that this input may not be useful to the majority of the farmers in the study area.

Table 3: Factory contracted services

\begin{tabular}{ll}
\hline Variable & Percentage $(\mathbf{n = 1 3 1 )}$ \\
\hline Contracted labour provision & 69.5 \\
Contracted provision of seed cane & 80.2 \\
Contracted provision of fertilizer & 72.5 \\
Contracted provision of agrochemicals & 2.3 \\
Contracted provision of extension & 64.9 \\
services & \\
Contracted provision of transport & 72.5 \\
services & \\
Contracted provision of cash credit & 70.2 \\
\hline
\end{tabular}

\section{Profitability of Sugarcane Production.}

Gross margin was used as proxy for profitability and was estimated using total variable costs and total revenues of farmers. Table 4 shows the results of the variable costs, revenues and the gross margin analysis. Total variable costs were derived from farmers' payment statements, farmers' handbooks or records as well as direct estimation from households. These costs included; survey charges, furrowing costs, cost of fertilizer, seed-cane charges, transportation, labour cost and harvesting charges. The kind and amount of cost incurred depended on whether the farmer is contracted or non-contracted, among other factors. The revenue was determined by the product of the selling price and the total yield. There are two sugarcane milling factories in the study area which are West Kenya and Butali. These 
Creative Commons User License: CC BY-NC-ND

Abstracted by: EBSCOhost, Electronic Journals Service (EJS),

Google Scholar, Journal Seek, Scientific Commons,

Food and Agricultural Organization (FAO), CABI and Scopus
Journal of Agricultural Extension

Vol. 25 (2) April, 2021

ISSN(e): 24086851; ISSN(Print); 1119944X

http://journal.aesonnigeria.org

http://www.ajol.info/index.php/jae

Email: editorinchief@aesonnigeria.org

factories however buy sugarcane at different prices which are KES. 4100 and KES. 3800 per tonne of sugarcane respectively. The price vary as these factories compete for sugarcane which is their main raw materials for production of sugar. Selling price therefore varied depending on which factory was chosen by the farmer. The findings indicate that on average the total revenue earned and cost incurred by a farmer are KES. 73841.15 and KES. 42848.64 per acre per season, respectively.

Gross margin was computed as the difference between gross revenue and total cost incurred per acre per season. From Table 4, it is indicated that, on average the gross margin is 30992.51 ranging from a minimum of KES. 69403 to a maximum of KES. 174900 per acre per season. This implies that farmers had a potential of earning a revenue of KES. 174900 per acre of sugarcane farm in every 14 to 18 months season.

Table 4: Variable costs, revenues and gross margin $(n=384)$

\begin{tabular}{llllll}
\hline Variable & & Mean & Std. Dev. & Min & Max \\
& & & & & \\
\hline Total variable costs per acre & 42848.6 & 22472.16 & 7660 & 16650 \\
(KES) & 4 & & & 0 \\
Total revenue earned per acre & 73841.1 & 39271.65 & 5700 & 25830 \\
$($ KES) & 5 & & & 0 \\
Gross margin (KES) & 30992.5 & 30561.31 & -69403 & 17490 \\
& 1 & & & 0 \\
\hline
\end{tabular}

\section{Comparison of Profitability of Contracted and Non-Contracted Sugarcane Farming}

The mean gross margins were determined for the contracted and noncontracted farmers. A summary of the mean gross margin for the two groups was as indicated in Table 5. The results showed that non-contracted farmers earn more profit than contracted farmers. Contracted farmers had a mean profit of KES. 21291.56 per acre while non-contracted farmers had a mean of KES. 36015.53 per acre as gross margin. Non-contracted farmers could earn KES 14723.97 more than contracted farmers per acre of sugarcane. Contracted farmers indicated that they were exorbitantly paying for cane transportation, ploughing, furrowing, seedcane, harvesting and fertilizer supply, among other costs. The increased costs of these inputs and services are as a result of high interest rates imposed by contracting factories. Moreover, non-contracted farmers get these inputs from other sources with no or low rates including family labour, obtain seed canes from neighboring harvested farms at low cost among other services. These findings concur with the results by Musungu and Sorre (2017). However, the findings contradict with those of Azumah et al. (2016) who indicated that contracted farmers were earning more income than non-contracted ones though in their 
study some of the contracted services had negative influence on income and others were insignificant.

$\begin{aligned} & \text { Table 5: Summary of gross margin earned by contracted and non- } \\
& \text { contracted sugarcane farmers }\end{aligned}$
\begin{tabular}{lll}
\hline Group & Mean & Standard deviation \\
\hline Contracted & 21291.56 & 32422.61 \\
Non-contracted & 36015.53 & 28336.75 \\
\hline
\end{tabular}

The results from one-way ANOVA in Table 6 show that the relationship between contract engagement and gross margin at farm level was very significant with $P$ value of 0.0000 . This implies that participation in factory contracted services was critical in explaining the variation of farmers' profitability in the study area.

Table 6: Contract engagement and profitability

\begin{tabular}{lllll}
\hline Source & SS & Df & MS & F \\
\hline Between groups & $1.8712 \mathrm{e}+10$ & 1 & $1.8712 \mathrm{e}+10$ & 21.08 \\
& & & & ${ }^{*}$ \\
Within groups & $3.3901 \mathrm{e}+11$ & 382 & 887455562 & \\
Total & $3.5772 \mathrm{e}+11$ & 383 & 933993709 & \\
\hline
\end{tabular}

$\mathrm{P} \leq 0.01$

\section{Effect of Selected Contracted Services on Sugarcane Profitability}

Seven contracted services offered by factories were used in assessing the effect of contracted services on the gross margin using multiple linear regression analysis. The results of the multiple regression analysis are given in Table 7. From the results, the effect of provision of extension and cash credit services was significant at $1 \%$. The effect of provision of labour was also significant at $5 \%$. The negative sign on provision of labour and cash credit services imply that participation in these services negatively affect the gross margin. On the other hand, provision of extension services was positive, implying that provision of these services increases gross margin of smallholder sugarcane farmers. However, provision of seed-cane, fertilizer, agrochemicals and transport services were found not to be significant at $5 \%$ level, implying that provision of these services might have no effect on farmers' gross margin. There was an $R^{2}$ of 0.4764 , implying that $47.64 \%$ of variation in profitability was accounted for by farmers' participation in contracted services. The mean Variance Inflation Factor (VIF) of 1.18 indicated that there was no problem of multicollinearity among the explanatory variables in the model. The conclusion of absence of multicollinearity problem in the data set was as guided by Mwangi et al. (2020) who postulated that when values of VIF are less than 10 or when a mean of the factors $(1 / \mathrm{VIF})$ is considerably less than 1 , then there is no problem of multicollinearity in the data set. 
Creative Commons User License: CC BY-NC-ND

Abstracted by: EBSCOhost, Electronic Journals Service (EJS),

Google Scholar, Journal Seek, Scientific Commons,

Food and Agricultural Organization (FAO), CABI and Scopus
Journal of Agricultural Extension

Vol. 25 (2) April, 2021

ISSN(e): 24086851; ISSN(Print); 1119944X

http://journal.aesonnigeria.org

http://www.ajol.info/index.php/jae

Email: editorinchief@aesonnigeria.org

Participation of farmers in factory contracted labour provision negatively affects the gross margin. Farmers' participation in this service decreases their income by about KES 11, 554 per acre of sugarcane. Sugarcane production in Kenya is a labour intensive activity. High labour is required during harvesting which drives farmers to seek for contracted labour services. Comparatively, contracted farmers were found to be incurring higher labour cost than non-contracted farmers. On average the total labour cost incurred by a contracted farmer is approximately KES 23,050 per acre per season, while a non-contracted is approximately KES 17,500 per acre per season. Contract service providers charge higher labour costs and interest resulting to a reduction of farmers' profitability. Similar results were found by Musungu and Sorre (2017) who argued that Mumias Sugar Company in Kenya had negatively impacted on farmers income due to high interest rates on their inputs including labour. However, the results contradict with those of Azumah et al. (2016) who found a positive influence of contracted labour on income in Ghana. However, though the later study found a positive influence the impact was too small where $1 \%$ increase in contracted labour could only increase income by $0.1 \%$ in Ghana.

Table 7: Effect of contracted services on profitability

\begin{tabular}{llll}
\hline Contracted provision & Coef. & Std. Err. & t-value \\
\hline Labour & $-11,554^{*}$ & 4946.114 & $-2.34^{*}$ \\
Seeds & 11,111 & 5853.517 & 1.90 \\
Fertilizer & 9,089 & 5332.855 & 1.70 \\
Agrochemical & 27127 & 14447.43 & 1.88 \\
Extension services & $24714^{\star *}$ & 5100.625 & $4.85^{\star *}$ \\
Transportation services & -3181.823 & 4865.566 & -0.65 \\
Cash credit services & $-21779^{\star *}$ & 4853.258 & $-4.49^{\star *}$ \\
Constant & 14766 & 7808.763 & 1.89 \\
Prob $>\mathrm{F}=0.0000$ & & & \\
R-squared $=0.4764$ & & & \\
Mean VIF $=1.18$ & & & \\
${ }^{* *} \mathrm{P} \leq 0.01 ;{ }^{*} \mathrm{P} \leq 0.05$ & & &
\end{tabular}

Similarly, provision of credit services negatively affect farmers income. Results show that participation of this service decreases farmers' income by KES 21, 779 per acre per season. With credit, farmers are expected to have access to productivity enhancing inputs such as fertilizer and seed-cane which are needed for the production of sugarcane that meet quality requirements set by the contracting factories. The negative influence revealed in the study is associated with the high cost of credit levied by contract service provider. Comparatively, the study revealed that noncontracted farmers get credit at lower costs as some obtain credit from informal sectors with low costs. This finding concurs with the Sugar Industry Stakeholders Taskforce Report by the Republic of Kenya (2020) which postulated that high cost of inputs and credit were negatively affecting 
farmers' gross margin. Rendering of extension services to farmers by sugar factories was however found to have a positive effect on the gross margin. Farmers who received contracted extension services were likely to increase their income by KES 24, 714 per acre. This relationship could be attributed to new technological know-how received by farmers to improve their sugarcane production yield. Similar results were found by Mwangi et al. (2020) and Mwololo et al. (2019).

However, provision of seed, fertilizer, agrochemicals, and transport services were found to be insignificant in the study area. This shows that rendering of these services by factories have no any influence on the gross margin of the farmers. The insignificant effect of these contracted services on gross margin can be associated with poor coordination of contracts (Dube \& Mugwagwa, 2017), a situation that was evident in the current study. The findings concur with those of Pradhan et al. (2016) who noted that sugarcane contracted farmers had not experienced a significant development as compared to non contracted farmers. The results by Azumah et al. (2016) also revealed insignificant effect for seed-cane though fertilizer was significant in their study.

The results show that participation in most contracted services had no impact on gross margin of smallholder farmers. Contracts have been confirmed to be beneficial to both farmers and contracting factories if they are managed effectively and both the parties are in a long-term relationship (Le-Ngoc, 2018). Therefore, the contracting factory need to assume part of the production and price risks and transfers some of the rights in decision making to contracted farmers (Mwambi et al., 2016) which is likely to impact positively on farmers' profitability.

\section{Conclusion and Recommendations}

On average, contracted farmers were less profitable compared to noncontracted farmers and the difference was statistically significant. Participation in factory provided extension services has a positive effect on gross margin, while the provision of labour and credit services have a negative effect on gross margin. The combined effect of participation in these services therefore provides enough evidence that farmers' participation in factory contracted services affect profitability of smallholder sugarcane farmers.

The Kenyan government through Agriculture and Food Authority- Sugar Directorate (AFA-SD) should develop input cost mechanism that guarantees low cost of production and high returns to smallholder sugarcane farmers. There is need for a review of the existing famer miller contracts to safeguard the abuse of buyer power. Furthermore, AFA-SD should formulate policies that enhance provision of contracted extension services among smallholder farmers which was found to have a positive effect on the gross margin. 
Creative Commons User License: CC BY-NC-ND

Abstracted by: EBSCOhost, Electronic Journals Service (EJS),

Google Scholar, Journal Seek, Scientific Commons,

Food and Agricultural Organization (FAO), CABI and Scopus

http://eoi.citefactor.org/10.11226/v25i2
Journal of Agricultural Extension

Vol. 25 (2) April, 2021

ISSN(e): 24086851; ISSN(Print); 1119944X

http://journal.aesonnigeria.org

http://www.ajol.info/index.php/jae

Email: editorinchief@aesonnigeria.org

\section{Disclosure statement}

No potential conflict of interest was reported by the authors.

\section{References}

Abdulai, Y., \& Al-hassan, S. (2016). Effects of contract farming on small-holder soybean farmers' income in the Eastern corridor of the Northern region, Ghana. Journal of Economics and Sustainable Development, 7 (2), 103113.

Azumah, S. B., Donkoh, S. A., \& Ehiakpor, D. S. (2016). Examining the determinants and effects of contract farming on farm income in the Northern Region of Ghana. Ghana Journal of Science, Technology and Development, 4(1), 1-10.

Bidzakin, J.K., Fialor, S.C., Awunyo-Vitor, D., \& Yahaya, I. (2020). Contract farming and rice production efficiency in Ghana. Journal of Agribusiness in Developing and Emerging Economies, 10(3), 269-284.

Chamberlain, W., \& Anseeuw, W. (2017). Inclusive businesses in South African agriculture. Stellenbosch: Sun Metro.

Dube, L., \& Mugwagwa, K.E. (2017). Technical efficiency of smallholder tobacco farmers under contract farming in Makoni district of Manicaland province, Zimbabwe: a Stochastic Frontier Analysis. Scholars Journal of Agriculture and Veterinary Science, 4 (2), 68-78.

Kenya National Bureau of Statistics (2019). Economic survey; The Kenya population and housing census. Government printers, Nairobi, Kenya, 23197064.

Kenya Sugar Board. (2016). Cane Census Report. Agriculture Department, Nairobi.

Kumar, A., Roy, D., Tripathi, G., Joshi, P.K., \& Adhikari, R.P. (2018). Does contract farming improve profits and food safety? Evidence from tomato cultivation in Nepal. Journal of Agribusiness in Developing and Emerging Economies, 8 (3), 603-624.

Le-Ngoc, H. (2018). Contract farming effects on technical efficiency of the exportoriented rice production sector in Vietnam. International Conference of Agricultural Economist.

Mdoda, L., \& Obi, A. (2019). Analysis of profitability of smallholder irrigated food plots in the Eastern Cape province of South Africa. J. Agribus. Rural Dev., 3(53), 225-232 
Creative Commons User License: CC BY-NC-ND

Abstracted by: EBSCOhost, Electronic Journals Service (EJS),

Google Scholar, Journal Seek, Scientific Commons,

Food and Agricultural Organization (FAO), CABI and Scopus
Journal of Agricultural Extension

Vol. 25 (2) April, 2021

ISSN(e): 24086851; ISSN(Print); 1119944X

http://journal.aesonnigeria.org

http://www.ajol.info/index.php/jae

Email: editorinchief@aesonnigeria.org

Mishra, A.K., Kumar, A., Joshi, P.K., \& D'Souza, A. (2018). Production risks, risk preference, and contract farming: impact on food security in India. Applied Economics Perspectives and Policy, 40 (3), 353.

Mulianga, B., Ogeda, I., \& Mwanga, D. (2015). Assessing the impact of climate change on sugarcane productivity in Kibos - Miwani, Kenya. Agricultural and Forest Meteorology, 16(4), 169 - 175.

Musa, K., Van, N. P., \& Retief, C. P. (2018). Challenges of contract farming among small-scale commercial vegetable farmers in Eastern Cape, South Africa. Journal of Agricultural Extension, 22 (3), 195-206.

Musungu, V., \& Sorre, M. B. (2017). Contract sugarcane farming and its effect on household income among smallholder farmers in Busia County, Kenya. International Journal of Science and Research Methodology, 7(4), 201 209.

Mwambi, M. M., Oduol, J., Mshenga, P., \& Saidi, M. (2016). Does contract farming improve smallholder income? The case of avocado farmers in Kenya. Journal of Agribusiness in Developing and Emerging Economies, 6(1), 2 - 20.

Mwangi, T. M., Ndirangu, S. N., \& Isaboke, H. N. (2020). Technical efficiency in tomato production among smallholder farmers in Kirinyaga County, Kenya. African Journal of Agricultural Research, 16(5), 667-677.

Mwololo, H. M., Nzuma, J. M., Ritho , C. N., \& Aseta, A. (2019). Is the type of agricultural extension services a determinant of farm diversity? Evidence from Kenya. Development Studies Research, 6(1), 40-46.

Pradhan, B., Singh, S. P., Ray, M. P., Singh, D. V., \& Badjena, T. (2016). Contract farming in sugarcane cultivation and development of growers. International Journal of Research in Applied, Natural and Social Sciences, $4(12), 2321-8851$.

Ragasa, C., Lambrecht, I., \& Kufoalor, D.S. (2017). Limitations of contract farming as a pro-poor strategy: The case of maize outgrower schemes in upper West Ghana. Intl Food Policy Res Inst, 1626.

Republic of Kenya. (2020). Sugar industry stakeholders taskforce report. Nairobi: Government of Kenya.

Sopheak , K. (2015). The effect of rice contract farming on smallholder farmers' income in Combodia. Journal of Agricultural Economics, 3(2), 43 - 51.

Wekesa, R., Onguso, M. J., Nyende, B., \& Wamocho, L. S. (2015). Sugarcane in vitro culture technology: opportunities for Kenya's sugar industry. African Journal of Biotechnology, 14(47), 3170 - 3178. 